\title{
Preliminary studies on differential expression of auditory functional genes in the brain after repeated blast exposures
}

\author{
Manojkumar Valiyaveettil, PhD; ${ }^{*}$ Yonas Alamneh, MS; ${ }^{1}$ Stacy-Ann Miller, BS; ${ }^{2}$ Rasha Hammamieh, PhD; ${ }^{2}$ Ying $^{1}$ \\ Wang, MD; ${ }^{1}$ Peethambaran Arun, PhD; ${ }^{1}$ Yanling Wei, MD; ${ }^{1}$ Samuel Oguntayo; ${ }^{1}$ Madhusoodana P. Nambiar, PhD $^{1^{*}}$ \\ ${ }^{1}$ Blast-Induced Neurotrauma Branch, Center for Military Psychiatry and Neuroscience, Walter Reed Army Institute of \\ Research, Silver Spring, MD; ${ }^{2}$ United States Army Center for Environmental Health Research, United States Army \\ Medical Research and Materiel Command, Fort Detrick, MD
}

\begin{abstract}
The mechanisms of central auditory processing involved in auditory/vestibular injuries and subsequent tinnitus and hearing loss in Active Duty servicemembers exposed to blast are not currently known. We analyzed the expression of hearingrelated genes in different regions of the brain $6 \mathrm{~h}$ after repeated blast exposures in mice. Preliminary data showed that the expression of the deafness-related genes otoferlin and otoancorin was significantly changed in the hippocampus after blast exposures. Differential expression of cadherin and protocadherin genes, which are involved in hearing impairment, was observed in the hippocampus, cerebellum, frontal cortex, and midbrain after repeated blasts. A series of calcium-signaling genes that are known to be involved in auditory signal processing were also found to be significantly altered after repeated blast exposures. The hippocampus and midbrain showed significant increase in the gene expression of hearing loss-related antioxidant enzymes. Histopathology of the auditory cortex showed more significant injury in the inner layer compared to the outer layer. In summary, mice exposed to repeated blasts showed injury to the auditory cortex and significant alterations in multiple genes in the brain known to be involved in age- or noise-induced hearing impairment.
\end{abstract}

Key words: auditory functional genes, auditory process, blast injury, cadherin, hearing loss, neurotrauma, otoancorin, otoferlin, protocadherin, tinnitus.

\section{INTRODUCTION}

Battlefield blast exposure is reported to cause auditory impairment in a large population of military personnel deployed to Iraq and Afghanistan [1-2]. Auditory/vestibular injuries from blast traumatic brain injury (TBI) can cause increased incidence of tinnitus and hearing loss, which worsens over time if not treated [1-4]. Shock waves generated from explosive blasts are reported to be destructive to both gas- and fluid-filled structures of the body, including the lungs, intestines, brain, eyes, nose, and middle ear [5-9]. Blast-induced damage to the auditory system can be the consequence of either direct exposure of the auditory canal to blast shock waves or TBI and impairment in the central auditory processing involving different brain regions after blast exposure. The literature on the neurobiological mechanisms of hearing impairment and development of tinnitus from blast TBI is limited.

\footnotetext{
Abbreviations: $\mathrm{cDNA}=$ complementary DNA, $\mathrm{TBI}=$ traumatic brain injury.

*Address all correspondence to Manojkumar Valiyaveettil, PhD, or Madhusoodana P. Nambiar, PhD; 503 Robert Grant Ave, Walter Reed Army Institute of Research, Silver Spring, MD 20910; 301-319-9679, ext 7307; fax: 301-319-9404. Emails: madhusoodana.nambiar@amedd.army.mil, m.valiyaveettil@amedd.army.mil
}

http://dx.doi.org/10.1682/JRRD.2011.09.0182 
A number of genes and their protein products have been reported to be involved in both age- and noise-related hearing loss [10-15]. Cadherin and protocadherin mutations were linked to digenic inheritance of deafness and have specific functional roles in noise-induced hearing loss [1314,16-17]. Other groups of proteins involved in deafness are otoferlin and otoancorin, which are also reported to have major roles in auditory functions, including central auditory processing [18-21]. Another large class of molecules involved in auditory signaling is centered on the calcium regulating proteins, which are known to have broad functions in age- and noise-related hearing loss or protection [18,22-26]. The significance of reactive oxygen species and heat shock proteins in age- and noise-related auditory impairments are also reviewed in detail [10,27-34].

Recent research on age- or noise-related hearing loss preferred mice as a suitable animal model because of the vulnerability of mice to sound compared to other rodents $[15,35]$. We have developed a preclinical mouse model of repeated blast exposures using an air-blast shock tube that closely mimics the repeated exposure to improvised explosive devices, grenades, or firing weapons used in the battlefield or breacher's studies [36-37]. The newly developed repetitive blast animal TBI model showed significant levels of neuropathology and neurobehavioral deficits after repeated blast exposures at 20.6 psi [36]. Using this mouse model of repeated blast exposures, we sought to determine differential expression of auditory-related genes in various regions of the brain by complementary DNA (cDNA) microarray analysis.

\section{METHODS}

\section{Animal Blast Exposure Model}

Experiments were performed in male mice (C57BL/ 6J, age 8-10 weeks, Jackson Laboratory; Bar Harbor, Maine). Groups of isoflurane (4\%) anesthetized animals ( $n=6$ for sham and $n=6$ for blast) were exposed to repeated blast exposures (20.6 psi), as reported previously, using a shock tube [9,36,38-39]. At a 6 h time point after the last blast exposure, three animals each from sham and blast groups were euthanized, and the brain tissue was collected after necropsy and separated into various regions as described earlier [39]. Different regions of the brain samples were immediately snap frozen and stored at $-80^{\circ} \mathrm{C}$ until use. Remaining animals $(n=3)$ in each group were sacrificed at $24 \mathrm{~h}$ after the last blast exposure and used for histopathology.

\section{Preparation of RNA}

Total RNA was isolated using Trizol reagent (Invitrogen Life Technology; Carlsbad, California) following the manufacturer's protocol. RNA quality and quantity were determined by using an Agilent 2100 Bioanalyzer (Agilent Technologies; Santa Clara, California).

\section{cDNA Microarray Analysis}

Microarray analysis was performed using Agilent 60-mer mouse genome $44 \mathrm{~K}$ oligo microarrays (Agilent Technologies). We labeled $5 \mu$ g of purified RNA with a commercially available kit (Agilent Low Input Quick Amp) by polymerase chain reaction amplification (Bio-Rad Laboratories; Hercules, California). Samples were fragmented and hybridized against universal mouse reference RNA (Stratagene; La Jolla, California) with a kit from Agilent. A 2-Color Microarray-Based Gene Expression Analysis (version 6.5) protocol was used for labeling and microarray processing. An Agilent G2565CA fluorescence scanner was used to quantitate the slides, and the resultant data were extracted using software (Agilent Feature Extraction, version 10.7.1). For filtering and normalization of the data, GeneSpring 10.1 software (Agilent) was used.

\section{Statistical Analysis}

The statistical analysis of the microarray data was performed with GeneSpring 10.1 software. Changes in the level of expression of various genes after blast exposure in comparison to sham controls were identified by Welsh's $t$-test statistical method ( $p$-values $<0.05$ ) in conjunction with multiple correction test (BenjaminiHochberg) with 5 percent false discovery rate. To account for the small sample size, we used the reference design and filtered for genes with signal intensities that are twice the standard deviation of the background intensity levels. We determined that by performing gene-by-gene $t$-tests, for a samples size of 3 and 5 percent false discovery rate and a standard deviation of 0.5 , the power is 75 percent. We also applied pathway and gene ontology analyses that offer extra power because it is statistically unlikely that a larger fraction of false positive genes end up in one specific pathway. 


\section{Histopathology of Auditory Cortex}

Histopathology was performed in blast-exposed and sham control mice ( $n=3$ in each group), as described previously [36]. Brain sections were silver stained and microscopically examined for neurodegeneration exclusively in the auditory cortex region, and the severity of injury was scored as mild $(+)$, moderate $(++)$ and severe $(+++)$.

\section{RESULTS}

\section{Expression of Auditory-Related Genes in Hippocampus After Repeated Blast Exposures}

The hippocampus of mice exposed to repeated blasts showed significant changes in the expression of multiple genes that are reported to be involved in age- or noiseinduced hearing loss (Table 1). Otoancorin, a gene defective in autosomal recessive deafness, showed a significant increase (3.4-fold), while otoferlin, which is essential for glutamate exocytosis at the auditory ribbon synapse, showed a 1.8-fold decrease in the expression after repeated blast exposures. The expression of calcium binding protein 2 showed a 1.6-fold increase, whereas calcitonin-related polypeptide expression showed a 1.9-fold decrease after blast exposures. The expression of antioxidant enzyme superoxide dismutase 3 showed a 2.0 -fold increase in the hippocampus of mice exposed to repeated blasts. The expression of heat shock protein 8 and heat shock transcription factor 5 showed significant increase in the hippocampus after repeated blast exposures. Protocadherin alpha 4 expression showed a 1.3-fold decrease after blast exposures.

\section{Expression of Auditory-Related Genes in Cerebellum After Repeated Blast Exposures}

The cerebellum of mice exposed to repeated blasts showed a 1.2-fold increase in protocadherins alpha 4 and beta 20 expression (Table 2). The expression of S100 calcium binding protein A7A showed a 1.4-fold increase, while multiple calcium channel proteins and calcium binding protein 2 expression showed a 1.1 to 1.2 -fold decrease in the cerebellum after repeated blast exposures. Heat shock protein 8 expression also showed a 1.1-fold decrease after blast exposures.

\section{Expression Profile of Auditory-Related Genes in Frontal Cortex After Repeated Blast Exposures}

The expression of calcium signaling-related molecules showed significant increase in the frontal cortex of mice

Table 1.

List of auditory-related genes significantly altered in hippocampus after repeated blast exposures in mice.

\begin{tabular}{|c|c|c|c|c|}
\hline $\begin{array}{l}\text { Gene } \\
\text { Symbol }\end{array}$ & $\begin{array}{c}\text { GenBank } \\
\text { Accession No. }\end{array}$ & Gene Product & Fold Change & $p$-Value \\
\hline$\overline{\text { Otoa }}$ & NM_139310 & Otoancorin & +3.4 & 0.04 \\
\hline Cabp2 & NM_013878 & Calcium binding protein 2 & +1.6 & 0.003 \\
\hline Sod3 & NM_011435 & Superoxide dismutase 3 & +2.0 & 0.03 \\
\hline Hspb8 & NM_030704 & Heat shock protein 8 & +1.3 & 0.02 \\
\hline Hsf5 & NM_001045527 & Heat shock transcription factor member 5 & +1.8 & 0.02 \\
\hline Otof & NM_031875 & Otoferlin & -1.8 & 0.04 \\
\hline Calca & NM_007587 & Calcitonin/calcitonin-related polypeptide alpha & -1.9 & 0.04 \\
\hline Pcdha4 & NM_007766 & Protocadherin alpha 4 & -1.3 & 0.001 \\
\hline
\end{tabular}

Table 2.

List of auditory-related genes significantly altered in cerebellum after repeated blast exposures in mice.

\begin{tabular}{lllcc}
\hline $\begin{array}{c}\text { Gene } \\
\text { Symbol }\end{array}$ & $\begin{array}{c}\text { GenBank } \\
\text { Accession No. }\end{array}$ & \multicolumn{1}{c}{ Gene Product } & Fold Change & $\boldsymbol{p}$-Value \\
\hline Pcdhb20 & NM_053145 & Protocadherin beta 20 & +1.2 & 0.03 \\
Pcdha4 & NM_007766 & Protocadherin alpha 4 & +1.2 & 0.03 \\
S100a7a & NM_199422 & S100 calcium binding protein A7A & +1.4 & 0.03 \\
Cacng1 & NM_007582 & Calcium channel, voltage-dependent, gamma subunit 1 & -1.2 & 0.003 \\
Cacna2d1 & NM_009784 & Calcium channel, alpha 2, delta subunit 1 & -1.1 & 0.049 \\
Efcab2 & NM_026626 & EF-hand calcium binding domain 2 & -1.1 & 0.01 \\
LOC641192 & XM_918536 & Similar to heat shock protein 8 & -1.1 & 0.046 \\
\hline \hline
\end{tabular}


exposed to repeated blasts, including calpain 3 (1.5-fold), S100 calcium binding protein A3 (1.4-fold), calcium/ calmodulin-dependent protein kinase kinase 1 (1.2-fold), and calcium binding domain 4A alpha polypeptide 7 (1.4fold) (Table 3). Protocadherin beta 11 and calreticulin expression showed significant decrease (2.2- and 1.2-fold, respectively) in the frontal cortex of mice exposed to repeated blasts.

\section{Expression of Auditory-Related Genes in Midbrain After Repeated Blast Exposures}

The changes in the expression of auditory-related genes in the midbrain of repeated blast-exposed mice are shown in Table 4. Expression of cadherin-like 24 showed a 1.8-fold increase, while expression of cadherin 12 and protocadherin 8 showed significant decrease (1.7- and 1.4-fold, respectively) after the blast exposures. Multiple calcium signaling molecules, including calpain 9 (2.1-fold), S100 calcium binding protein A3 (1.2-fold), and calcium activated potassium channel beta 3 (2.1-fold), showed significantly increased expression in the midbrain after repeated blast exposures. At the same time, the expression of calcium binding protein 7 (2.2-fold), calcium channel voltage dependent L type alpha 1D subunit (1.6-fold), and calcium/ calmodulin-dependent protein kinase 2 gamma (1.1-fold) showed significant decrease after repeated blast exposures. The midbrain of repeated blast-exposed mice also showed significant decrease in the expression of heat shock protein 2 (1.3-fold), nicotinic alpha polypeptide 7 cholinergic receptor (1.5-fold), and stanniocalcin 2 (1.3-fold).

\section{Histopathology of Auditory Cortex After Repeated Blast Exposures}

To investigate whether blast exposure induces pathology of the auditory cortex, neuropathology analysis of the

Table 3.

List of auditory-related genes significantly altered in frontal cortex after repeated blast exposures in mice.

\begin{tabular}{lllrr}
$\begin{array}{c}\text { Gene } \\
\text { Symbol }\end{array}$ & $\begin{array}{c}\text { GenBank } \\
\text { Accession No. }\end{array}$ & \multicolumn{1}{c}{ Gene Product } & Fold Change & p-Value \\
\hline Capn3 & NM_007601 & Calpain 3 & +1.5 \\
S100a3 & NM_011310 & S100 calcium binding protein A3 & +1.4 \\
Camkk1 & NM_018883 & Calcium/calmodulin-dependent protein kinase kinase 1 & +1.2 \\
Efcab4a & NM_001025103 & EF-hand calcium binding domain 4A alpha polypeptide 7 & +1.4 \\
Pcdhb11 & NM_053136 & Protocadherin beta 11 & -2.2 & 0.03 \\
Calr & NM_00759 & Calreticulin & -1.2 & 0.01 \\
\hline \hline
\end{tabular}

Table 4.

List of auditory-related genes significantly altered in midbrain after repeated blast exposures in mice.

\begin{tabular}{lllr}
\hline $\begin{array}{c}\text { Gene } \\
\text { Symbol }\end{array}$ & $\begin{array}{c}\text { GenBank } \\
\text { Accession No. }\end{array}$ & \multicolumn{1}{c}{ Gene Product } & Fold Change \\
\hline Cdh24 & NM_199470 & Cadherin-like 24 & +1.8 \\
Capn9 & NM_023709 & Calpain 9 & 0.02 \\
S100a3 & NM_011310 & S100 calcium binding protein A3 & 0.03 \\
Gpx4 & NM_008162 & Glutathione peroxidase 4 & 0.048 \\
Ccs & NM_016892 & Copper chaperone for superoxide dismutase & +1.2 \\
Kcnmb3 & NM_171828 & Calcium activated potassium channel beta 3 & +1.1 \\
Pcdh8 & NM_021543 & Protocadherin 8 & +1.1 \\
Cadh12 & NM_001008420 & Cadherin 12 & +2.1 \\
Cabp7 & NM_138948 & Calcium binding protein 7 & -1.4 \\
Cacna1d & NM_028981 & Calcium channel, voltage-dependent, L type, alpha 1D subunit & -1.6 \\
Camk2g & NM_178597 & Calcium/calmodulin-dependent protein kinase 2 gamma & -1.7 \\
Hspb2 & NM_178597 & Heat shock protein 2 & 0.03 \\
Chrna7 & NM_007390 & Cholinergic receptor, nicotinic alpha polypeptide 7 & 0.02 \\
Stc2 & NM_011491 & Stanniocalcin 2 & 0.04 \\
\hline \hline
\end{tabular}


brain of repeated blast-exposed mice was performed by silver staining. As shown in the Figure, a significant level of neurodegeneration occurred in the auditory cortex at $24 \mathrm{~h}$ after repeated blast exposures. The pathology index in the inner layer of auditory cortex (Figure(b2)) was scored as + to ++ , while the pathology index of the outer layer (Figure(a2)) was - to + compared to the respective sham controls.

\section{DISCUSSION}

Previous studies showed a significant level of neuropathology and neurobehavioral changes, with $\sim 20$ percent mortality rate after repeated blast exposures in mice at 20.6 psi [36]. The pathology was more evident in the prefrontal cortex and cerebellum of repeated blast-exposed mice. More recent results showed regional-specific changes in acetylcholinesterase activity in various regions of the brain after repeated blast exposures, indicating that the effects of blast exposure is heterogeneous in the brain [39]. The majority of the neurobiological changes in the brain were significant at $6 \mathrm{~h}$ after the last blast exposure [36]. Based on these observations, we analyzed the changes in the gene expression profile in different regions of the brain at $6 \mathrm{~h}$ after blast exposures in the present study.

The expression of otoferlin, which is known to be present in the brain and is essential for glutamate exocytosis at the auditory ribbon synapse and reported to be defective in a recessive form of human deafness, showed significant decrease in the hippocampus of mice exposed to repeated blasts [19-20,40-42]. In contrast, otoancorin, another hearing-related gene defective in autosomal recessive deafness and known to mediate the contact between the apical surface of sensory epithelial cells and acellular gels of the inner ear and the tectorial and otoconial membranes for proper auditory processing, showed significant increase in the hippocampus after repeated blast exposures [21,43]. Significant increase in the expression of otoancorin in the hippocampus after repeated blast exposures seems to be a compensatory mechanism to increase the sensitivity of hearing following injury to the auditory system and needs to be investigated in detail as a potential mechanism involved in the development of tinnitus.

Cadherins and protocadherins are another set of genes that showed differential expression in various regions of the brain after repeated blast exposures. Cadherin and protocadherin mutations are reported to be involved in noise-induced
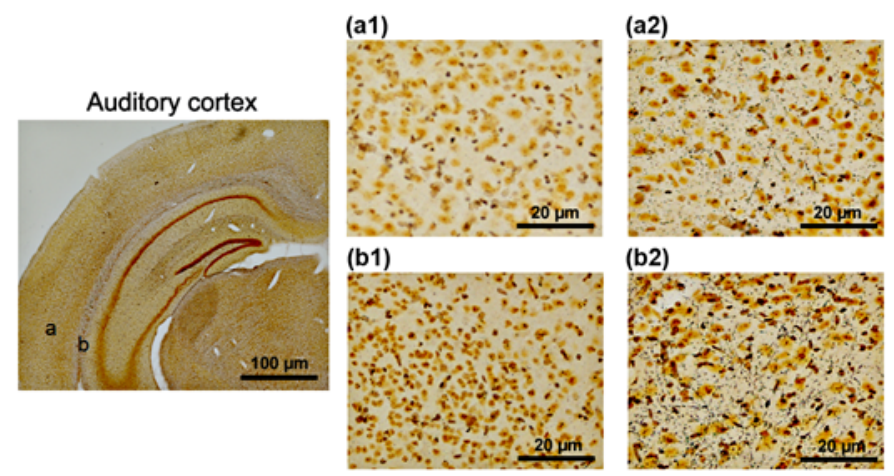

Figure.

Neuropathology of auditory cortex exposed to repeated blasts. Paraformaldehyde-fixed brain samples were sectioned into $50 \mu \mathrm{m}$ sections and stained with Neurosilver Kit II. Two different close proximities of auditory cortex indicated as (a) and (b) in left-most panel (labeled as "Auditory cortex") were analyzed for severity of injury in sham control ((a1) and (b1)) and repeated blastexposed ((a2) and (b2)) mice at $24 \mathrm{~h}$ after last blast exposure. Positive silver staining is evident in auditory cortex of repeated blast-exposed mice confirming neurodegeneration ( $n=3$ for sham and blast).

hearing loss [13-14,16-17,44]. The altered expression profile of cadherins and protocadherins in different regions of the brain after repeated blast exposures may impair central auditory processing. The functional significance of these gene modifications in the blast-induced impairment of central auditory processing has to be studied in detail to exploit them for therapeutic applications.

Molecules involved in calcium influx and calciumdependent proteins/enzymes are predominant signal transducers in auditory neurons [22-23,45-48]. The frontal cortex and midbrain of blast-exposed mice showed significant increase in the expression of calcium-dependent cysteine proteases and calpain 3 and 9, respectively (Tables 3 and 4). Calpains are essential for initiation and promotion of cell death, and treatment with calpain inhibitors are known to prevent the hearing loss induced by aminoglycoside ototoxicity [45]. The hippocampus of blast-exposed mice showed a significant decrease in the expression of calcitonin-related peptide, a suggested peptide therapeutic treatment for hearing loss (Table 1) [22,48]. The cerebellum and midbrain regions showed significant decrease in the expression of voltage-dependent calcium channel genes after repeated blast exposures, while multiple calcium binding proteins showed differential expression in the hippocampus, cerebellum, frontal cortex, and midbrain after repeated blast 
exposures (Tables 1-4). It is known that L-type voltagegated calcium channels are involved in the pathogenesis of acoustic injury in the cochlea, and treatment with calcium channel blockers can reduce the damage to the auditory neurons [26].

Other types of molecules involved in calcium regulation, such as calreticulin and calmodulin-dependent protein kinase expression, showed significant decrease in the frontal cortex and midbrain of blast-exposed mice, respectively (Tables 3 and 4) [23,47]. Interestingly, two calcium binding proteins, calretinin and parvalbumin, that were upregulated in the cerebellum at 24 and $48 \mathrm{~h}$ after blast exposures by proteomic analysis were not found to be altered in cDNA microarray analysis at $6 \mathrm{~h}$ after blast exposures. ${ }^{*}$ One possible reason for this difference is that calretinin and parvalbumin expression might be regulated at the translational level after blast exposures, which needs to be investigated further. Second, cDNA microarray analysis at 24 and $48 \mathrm{~h}$ after blast exposures needs to be done to find any significant changes in calretinin and parvalbumin gene expression. Western-blotting of the hippocampal region at $6 \mathrm{~h}$ after blast exposures showed significant increase in calretinin, further supporting the idea that blast exposure possibly modulates the protein expression at the translational level. The differential expression of calcium-dependent proteins/receptors in the brain after repeated blast exposures could be the consequence of increased/decreased calcium buffering in the auditory neurons. Thus, these results suggest that repeated blast exposures lead to an imbalance in the regulation of calcium homeostasis in different regions of the brain that can directly influence the central auditory processing and lead to auditory impairment.

Heat shock proteins or factors are one of the bestcharacterized families of protective proteins that are usually upregulated after stress, offering cellular protection and survival [10,27-28]. Repeated blast exposures in mice showed significant increase in the expression of heat shock protein 8 and factor 5 in the hippocampus, while cerebellum and midbrain showed significant decrease in heat shock protein 8 and heat shock protein 2, respectively (Tables 1, 2, and 4). The functional significance of heat shock proteins in hyper-

\footnotetext{
*Arun P, Valiyaveettil M, Biggemann L, Alamneh Y, Wei Y, Oguntayo S, Wang Y, Long JB, Nambiar MP. Modulation of hearing related proteins in the brain and inner ear following repeated blast exposures. Intervent Med Appl Sci. Forthcoming.
}

thermia and noise overstimulation is well documented $[10,28]$. The differential expression of heat shock proteins in the brains of repeated blast-exposed mice needs to be investigated further. Additionally, repeated blast exposure in mice showed significant reduction in the expression of the cholinergic receptor nicotinic alpha polypeptide 7 in the midbrain, suggesting a possible role of these receptors in aberrant central auditory processing (Table 4). The nicotinic receptor of cochlear hair cells has been proposed by others as a potential therapeutic target in acoustic trauma $[11,49]$.

The functional role of reactive oxygen species and the protective efficacy of antioxidants in noise-induced hearing loss are well documented [32,50-51]. Repeated blast exposure in mice showed significant increase in the expression of antioxidant enzymes, superoxide dismutase 3 , and glutathione peroxidase 4 in the hippocampus and midbrain, suggesting a protective mechanism in central auditory processing (Tables 1 and 4 ). The influence of glutathione peroxidase and superoxide dismutase in noiseinduced hearing loss has also been reported [12,31,33-34]. Reactive oxygen species showed an increase in the brain following repeated blast exposures [36].

Neuropathology analysis of the auditory cortex of repeated blast-exposed mice showed significant injury (Figure). The injury level was more on the medial contralateral side of the brain than the ipsilateral side. The neuropathology of the auditory cortex is in line with the significant level of auditory-related gene expression changes in the brain of blast-exposed mice. It is not clear whether the neuropathology is responsible for the changes in gene expression or vice versa. It has been reported that blast-induced mild to moderate TBI leads to neurobiological and behavioral changes with multifocal axonal injury [52-53]. In these reports, neuropathological changes were observed at 7 and $14 \mathrm{~d}$ after blast exposure, although gene expression changes were observed at day 1 , indicating that molecular changes contributes to the neuropathology. In our studies, neuropathology was prominent at $24 \mathrm{~h}$ after repeated blast exposures, but changes in gene expression were observed much earlier, suggesting that molecular changes can occur earlier as a direct effect of blast exposures. Preliminary data on brain DNA damage after blast exposure using comet assay showed breakage of DNA after repeated blast exposures. Studies with rats exposed to low-levels of explosive blast showed terminal dUTP nick end labeling-positive cells in the white matter in day 1 without any changes in day 7 [54]. 
Changes in many hearing-related genes after blast exposure in the brain indicate that these genes play specific roles in central auditory processing. The gene expression changes may be the consequence of initial protection against blast-induced central auditory processing and later as injury mechanism of central auditory processing. Gene expression changes can vary with respect to blast overpressure or number of blasts and may also depend on the severity of injury. The contribution of the shock waves transmitting through the auditory canal or directly through the skull in central auditory processing impairment is currently being investigated in the laboratory by using ear protection. Unraveling the functional role of these genes in central auditory processing and how they cross-talk with each of the brain regions to perform sound perception, hearing, speech recognition, and longterm memory will help us to understand how exactly their modulation plays a role in central auditory processing impairments. The linkage of these gene modulations to concurrent neuropsychiatric changes after blast exposure is also important to understand the complex neurobiological mechanisms of blast affecting central auditory processing and aid in rehabilitation.

\section{CONCLUSIONS}

In summary, preliminary results indicate that repeated blast exposures in mice showed significant alterations in multiple genes that are reported to be involved in age- or noise-related hearing loss at $6 \mathrm{~h}$ after blast exposure. The repeated blast exposure also showed significant neuropathology at $24 \mathrm{~h}$ in the auditory cortex, suggesting that blast exposure damages central auditory processing systems. Gene expression changes occur at early time points after blast exposure and may not be the consequence of apoptotic or necrotic changes in the brain. The gene expression profile showed differential pattern in various regions of the brain of mice exposed to repeated blasts. Otoferlin and otoancorin, which are involved in deafness, showed significant alteration in the hippocampus after repeated blast exposure. Similarly, cadherins and protocadherins, which are involved in noise-induced hearing loss, showed significant changes in all the brain regions tested. The expression profile of calcium-regulating proteins/receptors in various brain regions also showed differential expression, indicating an imbalance in calcium homeostasis after repeated blast exposures. The heat shock proteins and antioxidant enzyme expressions also showed significant changes in various regions of the brain after repeated blast exposure, indicating possible protective effects. The differential expression of multiple auditory-related genes in various regions of the brain after repeated blast exposures in mice needs to be investigated further to draw specific biochemical pathways involved in the functional significance of central auditory processing in blast-induced auditory dysfunction and tinnitus.

\section{ACKNOWLEDGMENTS}

\section{Author contributions:}

Study concept and design: M. Valiyaveettil, M. P. Nambiar. Acquisition of data: Y. Alamneh, S. Miller, Y. Wang, P. Arun, Y. Wei, S. Oguntayo.

Analysis and interpretation of data: Y. Alamneh, S. Miller, R. Hammamieh, Y. Wang, P. Arun, Y. Wei, S. Oguntayo, M. P. Nambiar. Drafting of manuscript: M. Valiyaveettil, M. P. Nambiar.

Study supervision: M. Valiyaveettil, R. Hammamieh, Y. Wang, P. Arun, M. P. Nambiar.

Financial Disclosures: The authors have declared that no competing interests exist.

Funding/Support: This material was unfunded at the time of manuscript preparation.

Additional Contributions: Collaborative help from COL Paul Bliese, Dr. Joseph Long, and Blast-Induced Neurotrauma Branch members is greatly acknowledged.

Institutional Review: Experiments were performed in compliance with the Animal Welfare Act and other Federal statutes and regulations relating to animals and experiments involving animals and adhered to principles stated in the Guide for the Care and Use of Laboratory Animals with an approved Institutional Animal Care and Use Committee protocol.

Disclaimer: The contents, opinions, and assertions contained herein are private views of the authors and are not to be construed as official or reflecting the views of the Department of the Army or the Department of Defense.

\section{REFERENCES}

1. Lew HL, Jerger JF, Guillory SB, Henry JA. Auditory dysfunction in traumatic brain injury. J Rehabil Res Dev. 2007; 44(7):921-28. [PMID:18075949] http://dx.doi.org/10.1682/JRRD.2007.09.0140

2. Fausti SA, Wilmington DJ, Gallun FJ, Myers PJ, Henry JA. Auditory and vestibular dysfunction associated with blastrelated traumatic brain injury. J Rehabil Res Dev. 2009; 46(6):797-810. [PMID:20104403]

http://dx.doi.org/10.1682/JRRD.2008.09.0118

3. Mao JC, Pace E, Pierozynski P, Kou Z, Shen Y, VandeVord PJ, Haacke EM, Zhang X, Zhang J. Blast-induced tinnitus and hearing loss in rats: behavioral and imaging assays. 
J Neurotrauma. 2012;29(2):430-44. [PMID:21933015]

http://dx.doi.org/10.1089/neu.2011.1934

4. Mrena R, Savolainen S, Kuokkanen JT, Ylikoski J. Characteristics of tinnitus induced by acute acoustic trauma: a longterm follow-up. Audiol Neurootol. 2002;7(2):122-30.

[PMID:12006740]

http://dx.doi.org/10.1159/000057660

5. Bauman RA, Ling G, Tong L, Januszkiewicz A, Agoston D, Delanerolle N, Kim Y, Ritzel D, Bell R, Ecklund J, Armonda R, Bandak F, Parks S. An introductory characterization of a combat-casualty-care relevant swine model of closed head injury resulting from exposure to explosive blast. J Neurotrauma. 2009;26(6):841-60. [PMID:19215189] http://dx.doi.org/10.1089/neu.2008.0898

6. Lew HL, Garvert DW, Pogoda TK, Hsu PT, Devine JM, White DK, Myers PJ, Goodrich GL. Auditory and visual impairments in patients with blast-related traumatic brain injury: Effect of dual sensory impairment on Functional Independence Measure. J Rehabil Res Dev. 2009;46(6): 819-26. [PMID:20104405] http://dx.doi.org/10.1682/JRRD.2008.09.0129

7. Dougherty AL, MacGregor AJ, Han PP, Heltemes KJ, Galarneau MR. Visual dysfunction following blast-related traumatic brain injury from the battlefield. Brain Inj. 2011; 25(1):8-13. [PMID:21117919] http://dx.doi.org/10.3109/02699052.2010.536195

8. Garman RH, Jenkins LW, Switzer RC 3rd, Bauman RA, Tong LC, Swauger PV, Parks SA, Ritzel DV, Dixon CE, Clark RS, Bayir H, Kagan V, Jackson EK, Kochanek PM. Blast exposure in rats with body shielding is characterized primarily by diffuse axonal injury. J Neurotrauma. 2011; 28(6):947-59. [PMID:21449683] http://dx.doi.org/10.1089/neu.2010.1540

9. Long JB, Bentley TL, Wessner KA, Cerone C, Sweeney S, Bauman RA. Blast overpressure in rats: recreating a battlefield injury in the laboratory. J Neurotrauma. 2009;26(6): 827-40. [PMID:19397422] http://dx.doi.org/10.1089/neu.2008.0748

10. Fairfield DA, Lomax MI, Dootz GA, Chen S, Galecki AT, Benjamin IJ, Dolan DF, Altschuler RA. Heat shock factor 1-deficient mice exhibit decreased recovery of hearing following noise overstimulation. J Neurosci Res. 2005;81(4): 589-96. [PMID:15952177] http://dx.doi.org/10.1002/jnr.20417

11. Shen H, Lin Z, Lei D, Han J, Ohlemiller KK, Bao J. Old mice lacking high-affinity nicotine receptors resist acoustic trauma. Hear Res. 2011;277(1-2):184-91.

[PMID:21272629]

http://dx.doi.org/10.1016/j.heares.2011.01.009

12. Keithley EM, Canto C, Zheng QY, Wang X, Fischel-Ghodsian $\mathrm{N}$, Johnson $\mathrm{KR}$. $\mathrm{Cu} / \mathrm{Zn}$ superoxide dismutase and age-related hearing loss. Hear Res. 2005;209(1-2):76-85.

\section{[PMID:16055286]}

http://dx.doi.org/10.1016/j.heares.2005.06.009

13. Zheng QY, Yan D, Ouyang XM, Du LL, Yu H, Chang B, Johnson KR, Liu XZ. Digenic inheritance of deafness caused by mutations in genes encoding cadherin 23 and protocadherin 15 in mice and humans. Hum Mol Genet. 2005;14(1):103-11. [PMID:15537665] http://dx.doi.org/10.1093/hmg/ddi010

14. Noben-Trauth K, Zheng QY, Johnson KR. Association of cadherin 23 with polygenic inheritance and genetic modification of sensorineural hearing loss. Nat Genet. 2003;35(1):21-23. [PMID:12910270] http://dx.doi.org/10.1038/ng1226

15. Ohlemiller KK, Wright JS, Heidbreder AF. Vulnerability to noise-induced hearing loss in 'middle-aged' and young adult mice: a dose-response approach in CBA, C57BL, and BALB inbred strains. Hear Res. 2000;149(1-2):239-47. [PMID:11033262] http://dx.doi.org/10.1016/S0378-5955(00)00191-X

16. Siemens J, Lillo C, Dumont RA, Reynolds A, Williams DS, Gillespie PG, Müller U. Cadherin 23 is a component of the tip link in hair-cell stereocilia. Nature. 2004;428(6986): 950-55. [PMID:15057245] http://dx.doi.org/10.1038/nature02483

17. Söllner C, Rauch GJ, Siemens J, Geisler R, Schuster SC, Müller U, Nicolson T; Tübingen 2000 Screen Consortium. Mutations in cadherin 23 affect tip links in zebrafish sensory hair cells. Nature. 2004;428(6986):955-59.

[PMID:15057246]

http://dx.doi.org/10.1038/nature02484

18. Beurg M, Michalski N, Safieddine S, Bouleau Y, Schneggenburger R, Chapman ER, Petit C, Dulon D. Control of exocytosis by synaptotagmins and otoferlin in auditory hair cells. J Neurosci. 2010;30(40):13281-90. [PMID:20926654] http://dx.doi.org/10.1523/JNEUROSCI.2528-10.2010

19. Schug N, Braig C, Zimmermann U, Engel J, Winter H, Ruth P, Blin N, Pfister M, Kalbacher H, Knipper M. Differential expression of otoferlin in brain, vestibular system, immature and mature cochlea of the rat. Eur J Neurosci. 2006;24(12):3372-80. [PMID:17229086] http://dx.doi.org/10.1111/j.1460-9568.2006.05225.x

20. Roux I, Safieddine S, Nouvian R, Grati M, Simmler MC, Bahloul A, Perfettini I, Le Gall M, Rostaing P, Hamard G, Triller A, Avan P, Moser T, Petit C. Otoferlin, defective in a human deafness form, is essential for exocytosis at the auditory ribbon synapse. Cell. 2006;127(2):277-89. [PMID:17055430] http://dx.doi.org/10.1016/j.cell.2006.08.040

21. Zwaenepoel I, Mustapha M, Leibovici M, Verpy E, Goodyear R, Liu XZ, Nouaille S, Nance WE, Kanaan M, Avraham KB, Tekaia F, Loiselet J, Lathrop M, Richardson G, Petit C. Otoancorin, an inner ear protein restricted to the interface between the apical surface of sensory epithelia 
and their overlying acellular gels, is defective in autosomal recessive deafness DFNB22. Proc Natl Acad Sci U S A. 2002;99(9):6240-45. [PMID:11972037] http://dx.doi.org/10.1073/pnas.082515999

22. El Sammaa M, Linthicum FH Jr, House HP, House JW. Calcitonin as treatment for hearing loss in Paget's disease. Am J Otol. 1986;7(4):241-43. [PMID:3740234]

23. Bolz H, Bolz SS, Schade G, Kothe C, Mohrmann G, Hess M, Gal A. Impaired calmodulin binding of myosin-7A causes autosomal dominant hearing loss (DFNA11). Hum Mutat. 2004;24(3):274-75. [PMID:15300860]

http://dx.doi.org/10.1002/humu.9272

24. Spencer RF, Shaia WT, Gleason AT, Sismanis A, Shapiro SM. Changes in calcium-binding protein expression in the auditory brainstem nuclei of the jaundiced Gunn rat. Hear Res. 2002;171(1-2):129-41. [PMID:12204357] http://dx.doi.org/10.1016/S0378-5955(02)00494-X

25. Ramakrishnan NA, Drescher MJ, Drescher DG. Direct interaction of otoferlin with syntaxin 1A, SNAP-25, and the L-type voltage-gated calcium channel Cav1.3. J Biol Chem. 2009;284(3):1364-72. [PMID:19004828] http://dx.doi.org/10.1074/jbc.M803605200

26. Uemaetomari I, Tabuchi K, Nakamagoe M, Tanaka S, Murashita H, Hara A. L-type voltage-gated calcium channel is involved in the pathogenesis of acoustic injury in the cochlea. Tohoku J Exp Med. 2009;218(1):41-47.

[PMID:19398872]

http://dx.doi.org/10.1620/tjem.218.41

27. Morimoto RI, Kline MP, Bimston DN, Cotto JJ. The heatshock response: regulation and function of heat-shock proteins and molecular chaperones. Essays Biochem. 1997;32: 17-29. [PMID:9493008]

28. Gong TW, Fairfield DA, Fullarton L, Dolan DF, Altschuler RA, Kohrman DC, Lomax MI. Induction of heat shock proteins by hyperthermia and noise overstimulation in hsf1 -/- mice. J Assoc Res Otolaryngol. 2012;13(1):29-37. [PMID:21932106] http://dx.doi.org/10.1007/s10162-011-0289-9

29. Ohlemiller KK, Wright JS, Dugan LL. Early elevation of cochlear reactive oxygen species following noise exposure. Audiol Neurootol. 1999;4(5):229-36. [PMID:10436315] http://dx.doi.org/10.1159/000013846

30. Ohlemiller KK, Dugan LL. Elevation of reactive oxygen species following ischemia-reperfusion in mouse cochlea observed in vivo. Audiol Neurootol. 1999;4(5):219-28. [PMID:10436314] http://dx.doi.org/10.1159/000013845

31. McFadden SL, Ohlemiller KK, Ding D, Shero M, Salvi RJ. The influence of superoxide dismutase and glutathione peroxidase deficiencies on noise-induced hearing loss in mice. Noise Health. 2001;3(11):49-64. [PMID:12689448]

32. Henderson D, Bielefeld EC, Harris KC, Hu BH. The role of oxidative stress in noise-induced hearing loss. Ear Hear.
2006;27(1):1-19. [PMID:16446561]

http://dx.doi.org/10.1097/01.aud.0000191942.36672.f3

33. Ohlemiller KK, McFadden SL, Ding DL, Flood DG, Reaume AG, Hoffman EK, Scott RW, Wright JS, Putcha GV, Salvi RJ. Targeted deletion of the cytosolic $\mathrm{Cu} / \mathrm{Zn}$-superoxide dismutase gene (Sod1) increases susceptibility to noiseinduced hearing loss. Audiol Neurootol. 1999;4(5):237-46.

[PMID:10436316]

http://dx.doi.org/10.1159/000013847

34. Ohlemiller KK, McFadden SL, Ding DL, Lear PM, Ho YS. Targeted mutation of the gene for cellular glutathione peroxidase (Gpx1) increases noise-induced hearing loss in mice. J Assoc Res Otolaryngol. 2000;1(3):243-54. [PMID:11545230] http://dx.doi.org/10.1007/s101620010043

35. Ohlemiller KK. Contributions of mouse models to understanding of age- and noise-related hearing loss. Brain Res. 2006;1091(1):89-102. [PMID:16631134] http://dx.doi.org/10.1016/j.brainres.2006.03.017

36. Wang Y, Wei Y, Oguntayo S, Wilkins W, Arun P, Valiyaveettil M, Song J, Long JB, Nambiar MP. Tightly coupled repetitive blast-induced traumatic brain injury: development and characterization in mice. J Neurotrauma. 2011;28(10):2171-83.

[PMID:21770761]

http://dx.doi.org/10.1089/neu.2011.1990

37. Kelley A, Athy J, Vasbinder M, Chiaramonte Rath E. The effect of blast exposure on sleep and daytime sleepiness in U.S. Marine Corps breachers. Washington (DC): U.S. Army Aeromedical Research Laboratory; 2010. Report No.: 2010-16.

38. Arun P, Spadaro J, John J, Gharavi RB, Bentley TB, Nambiar MP. Studies on blast traumatic brain injury using in-vitro model with shock tube. Neuroreport. 2011;22(8):379-84.

[PMID:21532394]

http://dx.doi.org/10.1097/WNR.0b013e328346b138

39. Valiyaveettil M, Alamneh Y, Oguntayo S, Wei Y, Wang Y, Arun P, Nambiar MP. Regional specific alterations in brain acetylcholinesterase activity after repeated blast exposures in mice. Neurosci Lett. 2012;506(1):141-45. [PMID:22079491] http://dx.doi.org/10.1016/j.neulet.2011.10.067

40. Pangrsic T, Lasarow L, Reuter K, Takago H, Schwander M, Riedel D, Frank T, Tarantino LM, Bailey JS, Strenzke N, Brose N, Müller U, Reisinger E, Moser T. Hearing requires otoferlin-dependent efficient replenishment of synaptic vesicles in hair cells. Nat Neurosci. 2010;13(7):869-76. [PMID:20562868] http://dx.doi.org/10.1038/nn.2578

41. Choi BY, Ahmed ZM, Riazuddin S, Bhinder MA, Shahzad M, Husnain T, Riazuddin S, Griffith AJ, Friedman TB. Identities and frequencies of mutations of the otoferlin gene (OTOF) causing DFNB9 deafness in Pakistan. Clin Genet. 
2009;75(3):237-43. [PMID:19250381]

http://dx.doi.org/10.1111/j.1399-0004.2008.01128.x

42. Reisinger E, Bresee C, Neef J, Nair R, Reuter K, Bulankina A, Nouvian R, Koch M, Bückers J, Kastrup L, Roux I, Petit C, Hell SW, Brose N, Rhee JS, Kügler S, Brigande JV, Moser T. Probing the functional equivalence of otoferlin and synaptotagmin 1 in exocytosis. J Neurosci. 2011;31(13): 4886-95. [PMID:21451027] http://dx.doi.org/10.1523/JNEUROSCI.5122-10.2011

43. Jovine L, Park J, Wassarman PM. Sequence similarity between stereocilin and otoancorin points to a unified mechanism for mechanotransduction in the mammalian inner ear. BMC Cell Biol. 2002;3:28. [PMID:12445334] http://dx.doi.org/10.1186/1471-2121-3-28

44. Ramakrishnan NA, Drescher MJ, Barretto RL, Beisel KW, Hatfield JS, Drescher DG. Calcium-dependent binding of HCN1 channel protein to hair cell stereociliary tip link protein protocadherin 15 CD3. J Biol Chem. 2009;284(5):3227-38. [PMID:19008224] http://dx.doi.org/10.1074/jbc.M806177200

45. Momiyama J, Hashimoto T, Matsubara A, Futai K, Namba A, Shinkawa H. Leupeptin, a calpain inhibitor, protects inner ear hair cells from aminoglycoside ototoxicity. Tohoku J Exp Med. 2006;209(2):89-97. [PMID:16707850] http://dx.doi.org/10.1620/tjem.209.89

46. Abaamrane L, Raffin F, Schmerber S, Sendowski I. Intracochlear perfusion of leupeptin and z-VAD-FMK: influence of antiapoptotic agents on gunshot-induced hearing loss. Eur Arch Otorhinolaryngol. 2011;268(7):987-93. [PMID:21246210] http://dx.doi.org/10.1007/s00405-011-1487-0

47. Kathiresan T, Harvey M, Orchard S, Sakai Y, Sokolowski B. A protein interaction network for the large conductance $\mathrm{Ca}(2+)$-activated $\mathrm{K}(+)$ channel in the mouse cochlea. Mol Cell Proteomics. 2009;8(8):1972-87. [PMID:19423573] http://dx.doi.org/10.1074/mcp.M800495-MCP200

48. Scherer EQ, Herzog M, Wangemann P. Endothelin-1induced vasospasms of spiral modiolar artery are mediated by rho-kinase-induced $\mathrm{Ca}(2+)$ sensitization of contractile apparatus and reversed by calcitonin gene-related peptide. Stroke. 2002;33(12):2965-71. [PMID:12468798] http://dx.doi.org/10.1161/01.STR.0000043673.22993.FD

49. Elgoyhen AB, Katz E, Fuchs PA. The nicotinic receptor of cochlear hair cells: a possible pharmacotherapeutic target?
Biochem Pharmacol. 2009;78(7):712-19.

[PMID:19481062]

http://dx.doi.org/10.1016/j.bcp.2009.05.023

50. Fetoni AR, Ralli M, Sergi B, Parrilla C, Troiani D, Paludetti G. Protective effects of N-acetylcysteine on noiseinduced hearing loss in guinea pigs. Acta Otorhinolaryngol Ital. 2009;29(2):70-75. [PMID:20111615]

51. Le T, Keithley EM. Effects of antioxidants on the aging inner ear. Hear Res. 2007;226(1-2):194-202.

[PMID:16843623] http://dx.doi.org/10.1016/j.heares.2006.04.003

52. Koliatsos VE, Cernak I, Xu L, Song Y, Savonenko A, Crain BJ, Eberhart CG, Frangakis CE, Melnikova T, Kim H, Lee D. A mouse model of blast injury to brain: initial pathological, neuropathological, and behavioral characterization. J Neuropathol Exp Neurol. 2011;70(5):399-416. [PMID:21487304] http://dx.doi.org/10.1097/NEN.0b013e3182189f06

53. Cernak I, Merkle AC, Koliatsos VE, Bilik JM, Luong QT, Mahota TM, Xu L, Slack N, Windle D, Ahmed FA. The pathobiology of blast injuries and blast-induced neurotrauma as identified using a new experimental model of injury in mice. Neurobiol Dis. 2011;41(2):538-51. [PMID:21074615] http://dx.doi.org/10.1016/j.nbd.2010.10.025

54. Pun PB, Kan EM, Salim A, Li Z, Ng KC, Moochhala SM, Ling EA, Tan MH, Lu J. Low level primary blast injury in rodent brain. Front Neurol. 2011;2:19. [PMID:21541261] http://dx.doi.org/10.3389/fneur.2011.00019

Submitted for publication September 30, 2011. Accepted in revised form February 7, 2012.

This article and any supplementary material should be cited as follows:

Valiyaveettil M, Alamneh Y, Miller S, Hammamieh R, Wang Y, Arun P, Wei Y, Oguntayo S, Nambiar MP. Preliminary studies on differential expression of auditory functional genes in the brain after repeated blast exposures. J Rehabil Res Dev. 2012;49(7):1153-62. http://dx.doi.org/10.1682/JRRD.2011.09.0182

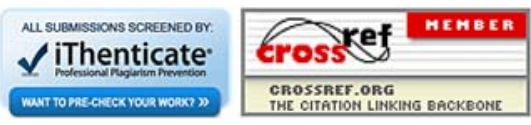

